\title{
CIHR spurns Aboriginal researchers' call for reconciliation
}

A boriginal health projects received less than $1 \%$ of the funding awarded by the Canadian Institutes of Health Research (CIHR) in its first major competition since restructuring — an outcome Aboriginal researchers say illustrates the need to reconcile the new system with the vast inequities in Indigenous health.

CIHR's decision-making style, which resulted in it going ahead with changes to funding despite objections from Indigenous and non-Indigenous researchers, "is not consistent with the recommendations of the Truth and Reconciliation Commission," says Rod McCormick, a Mohawk researcher and co-chair of the Aboriginal Health Research Steering Committee.

"There is no recognition or provision for the fact that systemic policies, when applied across the board, can have damaging impacts for groups that are different," McCormick told an emotionally charged meeting at the Wabano Centre for Aboriginal Health in Ottawa on Jan. 25.

In 2014/15, funding for Aboriginal health research was $\$ 31$ million, down from $\$ 34$ million at its annual peak 2004-2008, the Aboriginal Health Research Steering Committee reported.

McCormick and co-chair Frederic Wien, the principal investigator for the Atlantic Aboriginal Health Research Program, urged CIHR to revisit its changes and rebuild what Wien called "a respectful relationship with First Nations, Métis and Inuit people." Given the crisis in the health and well-being of many of these communities, the researchers want CIHR to prioritize Aboriginal health research.

CIHR's president denied any need for the federal agency to engage in reconciliation. "I would like to bring my personal views, not only those of CIHR, about the stormy weather we have been experiencing lately," Dr. Alain Beaudet told attendees at the January meeting. "But not in the spirit of

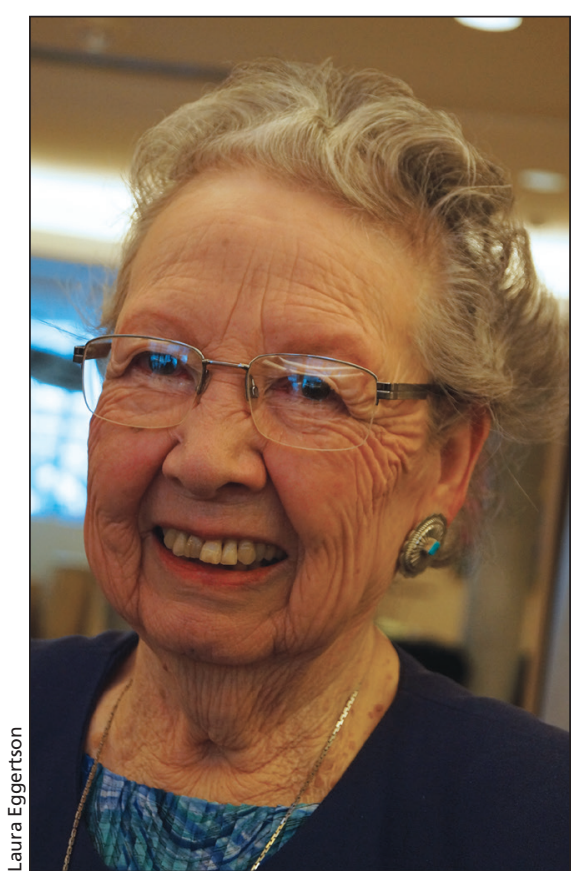

Marlene Brant Castellano, co-director of research for the Royal Commission on Aboriginal Peoples, believes CIHR is out of step with the Truth and Reconciliation Commission's recommendations.

reconciliation, because I don't think anything has been broken."

Beaudet made the remarks just three days after the shootings at La Loche, Saskatchewan. The murder of two teenagers, a teacher and a teacher's aide in the largely Dene community underscored for some attendees the crises in suicide, lack of mental health support and poverty that affect many Aboriginal youth and families.

Beaudet said Aboriginal health research is "extremely important" for CIHR, and its strategic investments will reflect that. CIHR has been working with the Aboriginal Health Research Steering Committee for 14 months and, according to the institute's media specialist David Coulombe, is committed to "co-building research initiatives" that "will improve the health of Canada's First Nations, Inuit and Métis peoples."

While Beaudet acknowledged both the magnitude of the recent changes and the fact that the Aboriginal health research budget has "flatlined," he said it has done so parallel to CIHR's overall budget. CIHR's billion-dollar annual federal budget has not increased since 2009, meaning that its spending power has declined by roughly $25 \%$ since then.

"We have gone through major changes at CIHR. I do not deny that," Beaudet said. "But I would deny ... that these changes are affecting particularly the Aboriginal community."

The Aboriginal Health Research Steering Committee contends that CIHR disadvantages researchers working in Aboriginal health through recent changes such as scrapping an Aboriginal-specific peer review process, requiring matching funds for several granting programs, and reallocating almost half the open competition funding for stellar emerging and establishing scholars.

But Beaudet said the changes promote more "out-of-the-box" research that will enable Canada to achieve more international success. He also suggested that those critical of the new system are afraid of change, and advised researchers that "looking back doesn't work." Learning from the past is a critical Indigenous value.

CIHR is starting to analyze the results of its initial investments, but it will take seven years for the new system to take full effect and before "meaningful" figures result, Beaudet said. "We'll work as quickly as we can, but we need the data. I'm saying 'Yes, trust us,' because if you look at CIHR's record, we've done a lot, and we've done it in good faith."

Most of the researchers and representatives of Aboriginal political organizations at the meeting did not seem inclined to trust Beaudet's reassurances.

"You're really saying to this group, 'Trust us.' And I just want to remind you that there's very little basis for trust," said Scott Serson, a former deputy minister of Indian Affairs and Northern Development, now with Canadians for a New Partnership, a group working 
for a new relationship between Indigenous and other Canadians.

The Aboriginal Health Research Steering Committee asked CIHR to set aside half a day at the June meeting of its governing council to address these issues. In an online statement, Beaudet acknowledged the request for an indepth discussion at "a future meeting" of the governing council. He also urged Indigenous health researchers and community members to apply as members of the new Institutes Advisory Board on Indigenous People's Health and a new College of Reviewers.

Marlene Brant Castellano, co-director of research for the Royal Commission on Aboriginal Peoples and the Mohawk elder who closed the meeting, described Beaudet and CIHR's response to the committee's requests as "disconnected" from the prevailing political environment.

Castellano, who is revered as the first Aboriginal full professor at a Canadian university, brought many in the audience to tears. Instead of recognizing the need for a new relationship between Canada and its Indigenous peoples, Beaudet's remarks echoed a too-familiar demand that Aboriginal researchers "get with" CIHR's program because, eventually, they would discover it was good for them, Castellano said.

"We have 400 years as Indigenous people trying to make things work in other people's agendas, and that is where we've gotten to the place now, where we still are, of watching our children dying," she said, tears streaming down her cheeks.
Beaudet had already left the meeting before Castellano went to the podium, and the two CIHR vice-presidents who had stayed for most of the discussion left as she began to speak, citing prior commitments. Only Malcolm King, scientific director of CIHR's Institute of Aboriginal Peoples' Health and a member of the Mississaugas of the New Credit First Nation, remained for the duration of the meeting.

According to Coulombe, Beaudet had a phone conversation with Castellano on Jan. 29, and "agreed to continue working collaboratively with community representatives and leaders in the future." - Laura Eggertson, Ottawa.

CMAJ 2016. DOI:10.1503/cmaj.109-5232 